\author{
Panych Hanna \\ Lecturer of Department of Foreign Phylology \\ Kyiv National University of Culture and Arts \\ ORCID 0000-0001-7244-0628 \\ hannusya.ukr@gmail.com \\ Rozumna Tetiana \\ Candidate of Pedagogical Scieces, \\ Assistant Professor of department of \\ Foreign Languages and Teaching Methods of BDPU \\ ORCID 0000-0002-1991-3016
}

\title{
METHODOLOGICAL ASPECTS OF THE USING THE GENRE OF IMPROVISATION AS A MEANS OF THE MANIFESTATION OF PERSONALITY CHARACTERISTICS IN A THEATRE OF COMEDY
}

\begin{abstract}
Purpose of Research. The purpose of the article is to analyse the using the genre of improvisation as a manifestation of personality characteristics in a theatre of comedy in the context of culture, language and customs. Methodology. The methodology of the research includes the art history and culturological approaches. The author applies the system-structural, analytical and comparative methods. They allow studying the particularities of various types of theatrical characters, which use both ordinary language and the language of physical gestures that are typical for English culture. The combination of the accessible language and visual conceptual immediacy makes it suitable for intercultural communication at different levels. Scientific Novelty. The scientific novelty of the article is the fact that this issues is the first, which are implemented in the course for future actors and students, who are studying a foreign language and culture. It has been implemented at Kyiv National University of Culture and Arts. The results of several months of an intensive theatre course are important for future projects and can be extrapolated to higher educational institutions in Ukraine. Conclusions. Thus, it has been found out that the theatrical workshops, based on the production of authentic, comedic texts, can provide rich and meaningful skills of foreign languages. Theatre courses can be used to learn a foreign language with understanding and interpretation of foreign literature and culture. In addition, the production process of the theatre encourages students to show their talents, challenge their abilities and achieve their goals in speaking any foreign language.

Key words: improvisation; personal characteristics; theatre of comedy; improvisational comedy; applied improvisation; dramatic interactions; communicative competence.
\end{abstract}

Розумна Тетяна Сергіївна, кандидат педагогічних наук, доцент кафредри іноземних мов і методики навчання Бердянського державного педагогічного університету; Панич Ганна Анатоліївна, викладач кафредри іноземної фрілології Київського національного університету культури і мистецтв медійному театрі

Методологічні аспекти використання жанру імпровізації як засобу прояву особистісних характеристик в ко-

Мета роботи. Дослідити використання жанру імпровізації як засобу проявлення особистісної характеристики в комедійному театрі з точки зору культури, її мови та звичаїв. Методологія дослідження полягає в застосуванні мистецтвознавчого та культурологічного підходів, системно-структурного, аналітичного та компаративного методів, що дозволяє дослідити особливості різних типів театральних персонажів, які для самовираження застосовують як звичайну мову, так і мову фізичних жестів, що є характерним для англійської культури. Саме таке поєднання доступної мови та візуальної концептуальної безпосередності робить її придатною для вивчення і настількиж неоціненною для міжкультурної комунікації на різних рівнях. Наукова новизна статті полягає у тому, що вперше означена проблематика актуалізована в контексті реалізаціїі курсу для майбутніх акторів та студентів, які вивчають іноземну мову та культуру. Такий проект був затверджений і впроваджений у Київському національному університеті культури і мистецтв. Результати декількох місяців інтенсивного театрального курсу мають велике значення для майбутніх проектів і можуть бути екстрапольовані на вищі навчальні заклади України. Висновки. В результаті дослідження встановлено, що повноцінні театральні майстерні, засновані на виробництві автентичних, комедійних текстів можуть надавати багаті та змістовні зв'язки в навчальній програмі іноземної мови. Курси театру можуть залучати до вивчення мови з розумінням та інтерпретацією літератури та культури. Крім того, виробничий процес театру заохочує учнів досліджувати свої таланти, кидати виклик своїм здібностям і досягати цілей володіння іноземною мовою комунікативно і високотворчо.

Ключові слова: імпровізація; особистісні характеристики; комедійний театр; імпровізаційна комедія; прикладна імпровізація; драматичні взаємодії; комунікативна компетентність.

Розумная Татьяна Сергеевна, кандидат педагогических наук, доцент кафедры иностранных языков и методики обучения Бердянского государственного педагогичного университета; Паныч Анна Анатольевна, преподаватель кафедры иностранной фрилологии Киевского национального университета культуры и искусств

Методологические аспекты использования жанра импровизации как средства проявления личностных характеристик в комедийном театре

Цель работы. Исследовать использование жанра импровизации как средства проявления личностной характеристики в комедийном театре с точки зрения культуры, ее языка и обычаев. Методология исследования заключается в применении искусствоведческого и культурологического подходов, системно-структурного, аналитического и сравнительного методов, что позволяет исследовать особенности различных типов театральных персонажей, которые для самовыражения применяют как обычный язык, так и язык фризических жестов, что характерно для английской культуры. Именно такое сочетание доступного языка и визуальной концептуальной непосредственности делает ее пригодной для изучения и столь же неоценимой для межкультурной коммуникации на разных уровнях. Научная новизна статьи заключается в том, что впервые данная проблематика актуализирована в контексте реализациии курса для будущих актеров и студентов, изучающих иностранный язык и культуру. Такой проект был утвержден и введен в Киевском национальном университете культуры и искусств. Результаты нескольких месяцев интенсивного театрального курса имеют большое значение для будущих проектов и могут быть экстраполированы на высшие учебные заведения Украины. Выводы. В результате исследования установлено, что полноценные театральные мастерские, основанные на производстве аутентичных, комедийных текстов могут предоставлять богатые и содержательные связи в учебной программе иностранного языка. Курсы театра могут привлекать к изучению языка с пониманием и интерпрета-

(c) Panych H., 2019

(C) Rozumna T., 2019 
цией литературы и культуры. Кроме того, производственный процесс театра поощряет учеников исследовать свои таланты, бросать вызов своим способностям и достигать целей владения иностранным языком коммуникативно и високотворчо.

Ключевые слова: импровизация; личностные характеристики; комедийный театр; импровизационная комедия; прикладная импровизация; драматические взаимодействия; коммуникативная компетентность.

Improv, short for "improvisation", is the art of creating theater on the spot with no script. Often scenes are created using input from the audience. Improv has deep roots leading back to 16th century Italy's Commedia dell'arte ("comedy of the profession"). Audiences would go to see recurring characters act out scenes which were vaguely structured, relying heavily on improvisation to tell their stories.

Modern improvisation took hold in the 1950's and 60's with Viola Spolin, Del Close, and Keith Johnstone's work. Improv came of age with Theatersports, which paved the way for many well-known comedy actors such as Tina Fey, Mike Myers and Steve Carell. The television show Whose Line is It, Anyway popularized improv, making it possible for smaller companies to spring up around the country. Improvisational theatre, often called improv or impro, is the form of theatre, often comedy, in which most or all of what is performed is unplanned or unscripted: created spontaneously by the performers. In its purest form, the dialogue, action, story, and characters are created collaboratively by the players as the improvisation unfolds in present time, without use of an already prepared, written script.

Improvisational theatre exists in performance as a range of styles of improvisational comedy as well as some non-comedic theatrical performances. It is sometimes used in film and television, both to develop characters and scripts and occasionally as part of the final product.

However, the skills and processes of improvisation are also used outside the context of performing arts which is called applied improvisation. It is used in classrooms as an educational tool and in businesses as a way to develop communication skills, creative problem solving, and supportive team-work abilities that are used by improvisational, ensemble players. It is sometimes used in psychotherapy as a tool to gain insight into a person's thoughts, feelings, and relationships.

Improv is unique in that if you see a performance, that's it... there will never be another show exactly like it ever done again. Improv is different every time. Improvised shows can differ between different improv troupes, depending on their training, their goals, and their style. Sometimes improv is purely comedy-based, while other times it can be a mix of both comedy and drama, or just drama. Like scripted theatre - without the script, with the actors acting, directing themselves, writing the plot, and interacting with each other all at the same time without previous planning.

Whereas the comedic genre tends to remain objective, portraying situations and events and how they unfold, umorismo is more subjective and bespeaks an author's worldview. In this sense, humor constituted a reaction to the social conventions of the day. It urges us to reflect upon the reasons for our laughter and makes us aware of the subtle connections between laughter and despair.

Drama techniques and theatrical games have been integral components of foreign language education for decades. They are part and parcel of numerous methodologies (i.e., The Natural Approach, TPR, The Communicative Approach, etc.) that favor interactive, task-based, and highly student-centered learning. Intrinsic to these methods are skits, "situations," scenarios, and role-plays which foster not only interactive but also creative uses of the target language, and can be adapted to different levels of instruction. The notion of role-play for educational purposes also extends beyond the endless possibilities for proficiency-building "situations" such as this: "you have arrived at the Airport for a 6- month stay in Scotland, but your luggage has not arrived for the moment, airport employees cannot even trace it". Murphey maintains that students can have real-life and rotating roles in class such as group secretary, suggestor, brainstorm leader, etc. Moreover, they might have roles in a multi-step tasks such as planning a party, a class trip, or preparing to host exchange students.

The benefits of such theater-based approaches and techniques for both children and adults are many (12, Savignon 14). Beyond improving fluency and accuracy over time, the regular use of situations and role-plays help build learner confidence in the oral mode. Needless to say, well contextualized dramatic interactions also foster cultural understanding in terms of customs, beliefs, and pragmatic language use - that is, competence in how and when to use the linguistic structures, registers, vocabulary, and gestures.

If we understand communication to be "the expression, interpretation, and negotiation of meaning" (Savignon 14), then true communication involves not only a variety of language skills but also paralinguistic knowledge and cultural understanding that changes with context or situation. Communicative competence, writes Savignon, is "a dynamic, interpersonal skill that applies to written and spoken language as well as other symbolic systems and is always context specific" (Savignon 14). Savignon also underscores the sociopragmatic aspects of communication by linking the notion of communicative competence to Speech Act Theory. The auther claims that although communication combines competence and proficiency, it is only observable through speech acts or "performance," and depends on all participants (Savignon 14). Referring to the work of Austin, Searle, and Fish, Savignon states that utterances are produced in certain situations by and for persons with specific intentions and purposes, and "can at best be evaluated according to degrees of competence" (Savignon 37). Consequently, upholding Canale and Swain's assertion that communication depends on much more than grammatical competence (linguistic accuracy). To the contrary, the latter linguists maintain that communication also depends on control of register and style (socio-linguistic compe- 
tence), on the ability to connect phrases and sentences into meaningful wholes (discourse competence), and on the way in which one compensates for limitations with the above (strategic competence) (Canale and Swain 6-12).

Communication also happens to be the first Standard in ACTFL's National Standards for Language Learning in the 21st Century and comprises three different modes - interactive, interpretative, and presentational. A course such as the English Theater Workshop described below, in which dramatic texts and techniques are the focus of all activities, efficiently and effectively lends itself to fostering participation in all three. For one, students engage in conversations and exchanges during each class meeting (and in between with classmates and professors) about numerous aspects of the play being produced. Second, students interact regularly with one or more authentic texts and must interpret meaning and express their interpretations in various written, oral, and corporeal forms. And third, students also make presentations to professors and peers about their characters, their set and design ideas, and about daily stage notes and stage directions. The "presentational" mode of communication culminates, of course, in the public performance of the play. It seems clear that theater texts and techniques can be rich and multifacted tools for mastering the complex task of successful and appropriate communication.

Year after year, the English Theater Workshop (ETW) proves highly conducive to the development of communicative competence, thanks to its numerous interactive components. Daily warm up games, for example, target the improvement of verbal and corporeal self-expression and provide opportunities for practice with the spontaneous "negotiation of meaning" inherent to true communication. Discussions of acting technique, line interpretation, and blocking, as well as costume, set, and lighting designs provide a truly meaningful (non-mechanical) context for communication. The focus on pronunciation and intonation not only helps students develop a more natural accent; it also shows them how intonation can completely alter the meaning of a sentence. The ITW, therefore, is not simply or solely an advanced language course. It is an upperdivision literature offering with a full-immersion setting that strives to incorporate intensive proficiency practice with literary comprehension and analysis skills. True, it generally revolves around the one play being performed, but the entire production process creates endless sub-contexts and situations for developing linguistic and analytic skills.

The students immediately grasped the comic potential of hiding an embarrassing situation from an important guest at a party. It is a common human experience, one that is consistent with societal norms in North America but greatly exaggerated in I/ Ciambellone to create a humoristic twist. The biggest challenge for the actors in working with this basic plot element was conveying their attempts to cut the cake with increasing intensity and urgency while keeping their movements and emotional expressions varied. For example, the actor who played Ludovico, one of the first characters to realize the problem with the cake, worked on expressing a range of sentiments starting with mild surprise and consternation and progressing through stages of determination, disbelief, enthusiasm for new ideas, disappointment, anger, rage, and insanity. Since unpredictability is a highly effective element of humor, clear transitions from one emotional state to the next were essential to the comedy of this scene; the audience never knew how the character would react next.

The growing intensity of the situation and the great lengths to which the characters must go to hide their secret contribute to the tension- ridden humor in the play.

Ciambellone was an excellent choice for beginners and intermerdiate- level students because the physical comedy was so easy to understand. Throughout the semester, actors worked to refine the timing of events such as the Athlete's attempt to karate chop the cake, the ciambellone's bouncing and rolling all over the room with the troupe tripping over one another in hot pursuit of it, and the hypnotist's dramatic efforts to mesmerize the cake, which ends up hypnotizing him instead. Another source of physical humor was the Athlete's myopic father, for despite the description of him as only "a little near-sighted," he continually mistakes one thing or person for another. Furthermore, students quickly learned to enhance their physical humor with "big" or exaggerated gestures, with large and colorful props, and with outlandish costume details. Behind the crazy antics of the play, however, remained the theme of a normal social situation gone awry. Thus, physical comedy proved a prelude to or indication of cutting socio-cultural commentary.

The English Theater Workshop.

In September 2018 the following project was implemented at Kiev National University of Culture and Art, fifty students participated in a production. The ITW was a graded course for credit and in the semester prior, the authors announced auditions in all intermediate and higher level English classes. The cast and crew comprised eight actors, a stage manager, a set designer, a costume designer, and a sound and lighting designer/technician. Four of these participants were advanced language students while the others had only completed the basic language sequence (one semester of intensive study) and were concurrently enrolled in an intermediate-level language class. From the middle of October to the late November opening night, actors rehearsed and designers had meetings two to three times per week for sixty to ninety minutes. In the last three weeks of production, rehearsals were five and six times per week, and 2-3 hours long. All were required 1) to participate in warm-up exercises at rehearsals and design meetings, 2) maintain a daily journal, and 3) write a final literary analysis of the play. Actors, stage managers, and designers then had separate responsibilities related to their production role. 
The director carefully selected warm-up exercises to accomplish specific linguistic, acting, and group-dynamic goals. For example, in the beginning stages of the workshop, warm-up games helped participants to feel at ease with one another and to get to know each other well. This immediately created a nonthreatening environment in which all, regardless of their proficiency, felt comfortable speaking in English. Note that warm-ups in the early stages tended to be less linguistically demanding, and more focused on building trust. But once the basic tone of the language community was set, the director selected more grammar- and communication- based exercises to begin each class. On a day-to-day basis, and in response to the difficulties and needs of the group, the director was able to employ games that focused on, for example, pronunciation, specific grammar points, or general improvisation of scenes. Finally, after the participants were much more familiar with the script, the director began to employ games that were more challenging in terms of language, and also in terms of the creativity, spontaneity, and quick thinking that they required. In one exercise that targeted the understanding and proper use of lines from the play (outside of the context of the play), the director assigned small groups of participants a scenario and gave each member of the group a specific character, entirely unrelated to the characters in the play. ("You are a waitress, mother, and young son at a high-class restaurant," for example.) The director also gave the group two or three expressions taken directly from the script. Students had only a minute or two to think before they had to improvise the scene, incorporating the assigned expressions in a natural and logical way. Other games explored character relationships and ways to convey humor with vocal intonation, bodily actions, positions, or gestures.

After an initial read-through of the entire text for general orientation and understanding, the troupe focused on a few scenes each week. The beginning stage involved close reading, in which students read scenes aloud very slowly, pausing for frequent discussions and clarifications. In this stage, actors would read a line silently to themselves, then repeat it aloud while looking into the eyes of the person to whom it was directed. This method of reading helped students better understand the intentions of the speaker as well as the emotional impact of the line upon the interlocutor. After the cast and crew had studied the entire script in this manner, the director began to add movements. From this point on, actors had to read on their own with a focus on memorization while designers scoured the dialogues and stage directions for ideas for costumes, set, lighting, and sound effects.

All workshop participants had to keep a journal in which they recorded their emotions, impressions, observations, questions, and suggestions after each rehearsal or meeting. In addition to helping students increase their comfort and fluency when writing in English, the journals enabled them to see their progress and in many ways facilitated their understanding of the script. The journals also gave students the chance to explore their ideas on different aspects of foreign language play production. Actors, for example, considered ways to add depth to their performance by analyzing their reactions to other characters in their writing. Designers thought through their choices of colors and styles for costumes and props, while keeping in mind the overall goal of using these elements to enhance the comic aspects of the show.

Students also wrote a literary analysis in a paper assignment consonant with those assigned in introductory-level literature courses. The analyses ranged from 5-7 pages in length. Learners also drew upon their close readings and classroom experiences to interpret social messages in the text.

All participants had role-specific responsibilities too. Actors memorized lines, movements, and nonverbal gestures. They also wrote a detailed analysis of their character and presented it to the cast and crew. Stage managers researched the biography of Campanile and the historical period in which he wrote. Their reports were distributed to cast and crew prior to the literary analyses, providing others with a reference point and bibliography for their own analyses of the play. Attending all rehearsals and design meetings, stage managers also kept track of line alterations, blocking changes, pronunciation errors, and general directions or comments during rehearsals. At design meetings they performed note-keeping functions and participated in discussions and troubleshooting. The designers focused their energy on the presentation of their plans mid-way through the workshop experience. Costume and set designers made large poster board displays for these presentations and conveyed their choices of colors, styles, sounds, songs, and images. The director accompanied the designers on shopping trips to find costumes, props, and supplies. And the director strove to preserve the immersion environment to the extent possible on these trips, continuing all conversation and negotiations in English.

The sound/lighting/publicity designer wrote sound and lighting cues and ran the sound and light boards for the show. They also compiled a "soundtrack" for the show, which she distributed to all participants, along with a list of the lyrics. The soundtrack included modern-day pop songs that the designer associated with the play in general or with certain characters as well as some traditional British music that was used at various points in the production itself.

The "tech week" of any show (the week before the show, including technical and dress rehearsals) is the most exhilarating and demanding time for the cast and crew. Actors realize that this is their last chance to refine pronunciation and delivery, adjust physical and facial reactions, perfect the timing of their lines and actions, and maximize comic effects. It is also a challenging period for designers who are finally able to see their ideas come to life. Yet at the same time they must tend to myriad details, adjustments, changes, and problems. During the "tech week," stage managers strive to establish a rhythm and pattern for preparing the 
stage in order to insure perfection of flow on opening night. They also take even greater responsibility for line notes and stage directions for cast and crew, under the director's guidance.

The first post-performance task is to strike the set - that is, remove, return, discard, or store all props and costume elements. An emotional let-down typically accompanies this phase, so we tried to soften it by holding a cast party. This included the distribution of soundtracks and commemorative t-shirts and the viewing of our videotaped production. Other ideas for channeling post-production energy included websites and photo albums for the department. These generated enthusiasm for future productions. Hence, at this time we quickly begin planning for the following year by recruiting, evaluating scripts, and setting dates for auditions and shows.

The student progress was evaluated in a variety of ways throughout the ITW experience. These ranged from short-answer exams on a computer and oral proficiency interviews to numerous writing assignments and class presentations. The short-answer pre- and post-tests were designed and implemented with course management software. This exam tested 1) active vocabulary of the course and general theater vocabulary such as "stage," "script," and "scenery" (students were asked to give the equivalent in English); 2) reading comprehension (plot and character motivation question); and 3) selected grammar structures (subjunctives, object pronouns, relative pronouns).

Clearly, certain factors inherent to the nature of the ITW course here described make it difficult to quantify linguistic gains during the 12-week experience. Among such factors are 1) the numerous variables among participants in terms of their backgrounds with English language studies and, hence, their proficiency levels at the start of the workshop, 2) students' personal motivation and dedication in terms of independent study time and practice, and 3) students' concurrent enrollment in other English language or literature courses.

Nonetheless, the authors conducted a three-way analysis of variance to compare the differences in results between actors and non-actors on the pre- and post-tests in three main categories of vocabulary, reading comprehension, and grammar. The 2 (test: pre- and post-test) $\times 2$ (type: actor vs. non-actor) $\times 3$ (category: vocabulary, reading, grammar) anova used to calculate participants' performance revealed that there was a highly significant main effect for test, $F(1,102)=40.34, p<.0001$ and a highly significant main effect for category, $F(1,102)=99.31, p<.0001$. This means there was a significant improvement in student performance between pre- and post-test. In addition, there was a significant difference among the categories tested. In fact, we find the interaction between test and category to be highly significant $F(1,102)=27.37, p$ $<.0001 .{ }^{16}$ This means that there was not improvement in all categories.

Looking more closely at the interaction between test and category, the means from each category (see table 1) reveal that students improved in vocabulary and grammar, but not in reading comprehension.

Table 1. Pre- and Post-production language test scores.

\begin{tabular}{|l|l|l|l|l|l|}
\hline Pre-Test & & & Post-Test & & \\
\hline Category & Type & & Category & Type & \\
\hline & Actors & Non-actors & & Actors & Non-actors \\
\hline Vocabulary & 12.60 & 10.86 & Vocabulary & 28.00 & 25.00 \\
\hline Grammar & 12.60 & 12.86 & Grammar & 14.70 & 14.71 \\
\hline Reading & 4.40 & 3.71 & Reading & 4.10 & 4.29 \\
\hline
\end{tabular}

While this discrepancy may be due to the fact that there were not enough test items to accurately gauge performance for reading comprehension, it is also possible that reading and understanding a new literary text within certain time constraints (as opposed to working with it regularly over several weeks' time) is a more difficult skill to improve in 12-13 weeks. Or the post-test reading sample may have simply been more difficult for the class.

Perhaps one surprising discovery in these results is the lack of interaction between test and type, meaning that there was no significant difference between the performance of actors and non-actors. Generally, one might assume that those participants required to repeatedly read aloud and memorize lines would naturally perform better in test sections such as vocabulary and grammar. However, this was not the case. The authors attribute this lack of discrepancy to the holistic and all-inclusive design of the course. Stage managers and designers had to attend all classes and rehearsals unless they were working on a specific task outside of the workshop setting (building, purchasing, mixing tapes, noises, and music for sound, etc.). Moreover, they participated in all aspects of the rehearsals namely, warm-up games, lectures, discussions, instructions, read-throughs, blocking, pronunciation exercises, and stage notes. And as the performances drew closer, designers were in charge of discussing and giving directions pertaining to costumes, props, lighting, actors' positions, vocal projection, and emotions.

Oral proficiency was tested separately during weeks 1 and 12. Students sat for individual interviews with the faculty director trained in OPI testing. As per the ACTFL guidelines, these interviews explored a variety of topics, and through a role-play scenario, varied the context of conversation to test different linguistic 
registers and vocabulary. However, since these interviews were not double-rated, they were unofficial and thus valid only for immediate classroom purposes. While it is admittedly very hard, if not impossible to improve by an entire sub-level in the course of a 14-week period, the authors attribute the gains in most borderline cases (students verging on the higher sub-level at the time of the pretest) and to the full-immersion nature of the workshop, particularly in the final weeks when rehearsals were 2-3 hours in length and became more frequent, almost every day.

Table 2. Participants' Language Study Background and (unofficial) OPI ratings.

\begin{tabular}{|l|c|l|l|l|l|}
\hline Role & $\begin{array}{c}\text { Concurrent } \\
\text { English } \\
\text { Class }\end{array}$ & $\begin{array}{l}\text { Previous } \\
\text { Study Abroad }\end{array}$ & $\begin{array}{l}\text { Pre- } \\
\text { Production } \\
\text { OPI (unofficial) }\end{array}$ & $\begin{array}{l}\text { Post- Production } \\
\text { OPI (unofficial) }\end{array}$ & $\begin{array}{l}\text { Perceived } \\
\text { Improvement }\end{array}$ \\
\hline Actor & 201 & No & IL & IH & 2 sub-levels \\
\hline Actor & 201 & No & NH & IM & 2 sub-levels \\
\hline Actor & 201 & No & IM & IH & 1 sub-level \\
\hline Actor & 201 & No & I & IM & 1 sub-level \\
\hline Actor & 201 & No & IH & AL & 1 sub-level \\
\hline Actor & 499 & 1 semester & IH & AL & 1 sub-level \\
\hline Actor & 499 & 1 semester & AL & AM & 0 \\
\hline Actor & 248 & $\begin{array}{l}\text { No (native } \\
\text { Spanish } \\
\text { speaker) }\end{array}$ & AL & AL & \\
\hline Designer & 201 & No & IH & IH & 0 \\
\hline Designer & 248 & No & IM & IH & 1 sub-level \\
\hline Stage Manager & 201 & No & I & IM & 1 sub-level \\
\hline
\end{tabular}

In addition to the OPIs, the authors evaluated communicative competence gradually and informally throughout the semester during rehearsals, class discussions, and presentations of characters, sets, and designs. While students clearly made gains in grammatical competence, socio-linguistic competence, and discourse competence to differing degrees, the most improvement across the board was in strategic competence - their ability to rephrase, paraphrase, gesticulate, ask questions, etc. - to continue or bring to fruition a given conversation. The authors attribute this advance to the rich variety of theater games used as warmups at the start of each class period, as well as to the urgency and importance of the task at hand. In addition to reducing students' apprehension, successful completion of tasks nudged students to work with their bodies, faces, and strategies to express themselves with clarity and precision. As a result, they employed conversational strategies and non-verbal elements with greater ease by the end of the semester.

The final component of workshop assessment was a survey of how students perceived their foreign language abilities before and after the play. During weeks 1 and 12 students rated themselves on a scale from 1-10 on their knowledge/proficiency in speaking, listening, reading, writing and culture. These included over 30 sub-skill categories such as "ability to use new vocabulary in speaking/" "grammatical accuracy in writing/" "feeling at ease reading authentic texts/', "understanding of non-verbal gestures/' etc.

We conducted a three-way analysis of variance to compare the differences in results between actors and non-actors on the pre- and post- perceptions questionnaires and in the five main skill categories of speaking, listening, reading, writing, and culture. There was a highly significant main effect for test, $F(1,132)$ $=34.7, p<.0001$ and a significant main effect for the type, $F(1,132)=7.78, p<.01$. This means that all students thought that they improved in all categories as a result of the ITW experience. It also means, however, that there was a significant difference in the perceptions of actors and non-actors that did not change from the pre- to the post-test (as evidenced by the lack of interaction between type and test). Somewhat surprisingly, the non-actors not only thought that they improved as much as the actors, but also departed from a higher self-estimate of their skills. Instead, there was no significant effect on the category (various language skills and culture).

Table 3. Students' perceived level of ability in main skill areas and culture

\begin{tabular}{|l|l|l|l|l|l|}
\hline IPre-Test & & & Post-Test & & \\
\hline Category & Type & & Category & Type & \\
\hline & Actors & Non-actors & & Actors & Non-actors \\
\hline Speaking & 4.91 & 5.04 & Speaking & 6.16 & 6.96 \\
\hline Listening & 5.73 & 6.63 & Listening & 7.30 & 8.07 \\
\hline Reading & 5.40 & 6.80 & Reading & 6.95 & 7.87 \\
\hline Writing & 4.18 & 5.63 & Writing & 6.15 & 7.43 \\
\hline [Culture & 4.47 & 4.92 & Culture & 6.81 & 6.75 \\
\hline
\end{tabular}


At the level of numeric averages for all participants, the smallest overall perceived improvement was in the categories of "general pronunciation" and "intonation" and "vocabulary recognition in reading" and "grammar recognition in reading," respectively. Instead, the greatest perceived improvement categories were use of "knowledge of idioms," "knowledge of gestures," and "use of new vocabulary in writing."

The lowest scores reported, though still perceived improvement, suggest that we should give more attention to pronunciation and intonation during the production process, particularly for the non-actors who, unlike the actors, do not participate in small-group or individual pronunciation sessions between class meetings. The perceptions of vocabulary and grammar recognition mirror the fact that after the initial group readthrough, and the students' independent interaction with the primary theatrical text, reading is the skill least called upon in the ITW setting.

The highest perceived gains in knowledge of idioms and use of vocabulary in writing may reflect the new lexical and cultural contexts that the theater workshop itself provided. The dynamic and interactive nature of the class made understanding the text, each other, and the director an absolute necessity at all times. That is, it forced students to focus on what was unfamiliar and led to new understanding and eventually to the spontaneous use of new terms and phrases. Finally, the perceived improvement in knowledge of gestures is likely attributable to the fact that the theater workshop is one of few contexts in which students learn to communicate (express, comprehend, negotiate meaning) in English with whole-body movements, facial expressions, and non-verbal gestures.

Conclusions and Recommendations. Individually and collectively, students made gains not only in terms of linguistic competence and proficiency, but also in terms of their ability to understand and analyze authentic literary texts. Most important, perhaps, is the fact that students perceived improvement in their skills and, consequently, grew in confidence as members of this second-language community.

At the same time, each year the authors identify areas for improvement and items to change in terms of course design and assessment procedures. For example, they highly recommend adding a decisive phonetics/pronunciation component to the course, not only for actors but also for managers and designers. Preferably, a mother-tongue member of the faculty would offer this tutorial, and even better if s/he has interest in fiction or drama. With regard to assessment, it would prove interesting to conduct official, double-rated Oral Proficiency Interviews in weeks 1 and 12, and then again after another 12-week period (delayed post-test) to assess the duration of workshop effects on oral proficiency. In addition, a delayed post-test on vocabulary, reading, and grammar would provide useful information about the longevity of linguistic gains from the theater workshop experience, as would a delayed task-based test (much like the warm-up games through which communicative competence was observed throughout the semester) to gauge longer-term gains in communicative competence.

\section{References}

1. Angelini. F. II teatro del Novecento da Pirandello a Fo. Bari: Later/a, 1990. Brauer, Gerd. ed. Body and Language: hitercultural Learning Through Drama. Wcstport, CT: Ablex. 2002.

2. Canale M. "From Communicative Competence to Communicative Language Pedagogy." Language and Communication. Ed. J. Richards and R. Schmidt. London: Longman, 1983.

3. Canale M., Merrill S. "Theoretical Bases of Communicative Approaches to Second Language Teaching and Testing." Applied Linguistics I (1980): 1-47.

4. $\quad$ Devin, Sean. "Interacting with Authentic Texts: Multi-Layered Processes." Modern Language Journal 81.4 ( 1997): 457-

69.

5. Dodson S. "Language Through Theater: Using Drama in the Language Classroom."Texas Papers in Foreign Language Education $5.1(2(\mathrm{XX}))$ : $129-42$.

6. Faulhaber U. "Laboratory Theater: An Addition to the Foreign Language Curriculum." Unterrichtspraxis I (1973): 36-39.

7. 7. Haggstrom M. "A Performative Approach to the Study of Theater: Bridging the Gap between Language and Literature Courses." French Review I (1992): 7-19.

8. Lederer H. The Play's the Thing: The Use of Theater in Language Learning."Studies in Language Learning 3.2 (1981):

35-41.

9. Lee J. Bill Van P. Making Communicative Language Teaching Happen. 2nd. ed. New York: McGraw Hill. 2003.

10. Mather C. "Getting off the Page and Making a Scene: Teaching Drama in the Classroom." ADFL Bulletin 20 (1989): 58-

63.

11. Moody D. "Undergoing a Process and Achieving a Product: A Contradiction in Educational Drama?" Briiucr 135-60.

12. Nunan D. Designing Tasks for the Communicative Curriculum. Cambridge, UK: Cambridge UP, 1989.

13. Rivers W. Interactive Language Teaching. New York: Cambridge UP, 1987.

14. Savignon S. Communicative Competence. Theory and Classroom Practice. 2nd. ed. New York: McGraw Hill. 1997.

15. Savoia F. "Teaching Italian Language, Literature, and Culture Through Performance: The Italian Theatrical Workshop." Italica 11A (2002): 509-22.

16. Schewe M., Shaw P. Towards Drama as a Method in the Foreign Language Classroom. Frankfurt am Main: Peter Lang. 1993.

17. Shier J. "Integrating the Arts in the Foreign/Second Language Curriculum: Fusing the Affective and the Cognitive." Foreign Language Annals 23.4 (1990): 301-16.

18. Smith S. The Theater Arts and the Teaching of Second Languages. Reading, MA: Addison-Wesley, 1984.

19. Standards for Foreign Language Learning in the 21 st Century. New York: National Standards in Foreign Language Education Project, 1999.

20. Taviani F. "Introduzione." L'inventore del cavallo e altre 15 commedie, by Achille Campanile. Milan: Bur, 2002.

21. URL: www.campanile.it/index/ind_biog.htm. 